\title{
RELATIONSHIP BETWEEN SEED TECHNOLOGY RESEARCH AND FEDERAL PLANT BREEDING PROGRAMS
}

\author{
F. C. KRZYZANOWSKI ${ }^{1,2}$ \\ ${ }^{1}$ EMBRAPA/Soja, C.P. 231, CEP: 86001-970 - Londrina, PR, Brasil. \\ ${ }^{2}$ Bolsista do CNPq
}

\begin{abstract}
This paper deals with the contributions seed technology can provide for soybean breeding programs for seed quality. Efforts can be placed on seed quality assurance (DIACOM) to assist the production system, from genetic up to certified seed in releasing a product of high quality. Another approach is the development of screening methods, based on seed technology tests (vigor tests), for selecting genotypes according to different traits relating to seed quality. An understanding of seed quality mechanisms, such as seed-coat properties, pod-wall permeability, seed and pod resistance to fungi infection, seed shriveling and cell wall permeability, will help to define the screening procedures for this characteristic. It has been one of the most important contributions that seed technology can provide for the improvement of crops grown in tropical and subtropical environments.
\end{abstract} Key Words: seed, soyabean, plant breeding

\section{RELAÇOES ENTRE A PESQUISA EM TECNOLOGIA DE SEMENTES E OS PROGRAMAS DE MELHORAMENTOS DE PLANTAS EM INSTITUIÇÕES OFICIAIS}

RESUMO: O escopo principal deste trabalho é relatar as contribuições que a tecnologia de sementes pode oferecer para os programas de melhoramento genético da soja para qualidade de semente. Colocadas no sistema de controle de qualidade (DIACOM) visam assegurar a produção de sementes de alta qualidade desde a classe genética até a certificada. Uma outra interação importante é o desenvolvimento de métodos para seleção de genótipos com alta qualidade de sementes com base nos testes de vigor. $O$ entendimento dos mecanismos determinantes da qualidade da semente, tais como as propriedades do tegumento, a permeabilidade da vagem, as resistências da vagem e da semente à entrada de fungos, o enrugamento da semente devido a estresse de temperatura e umidade e a permeabilidade da membrana celular da semente, poderão auxiliar na definição dos procedimentos metodológicos para a seleção de germoplasma com característica de semente de alta qualidade. O que será uma das mais importantes contribuições que a tecnologia de sementes pode oferecer para a melhoria das espécies cultivadas nas regiões tropicais e subtropicais.

Descritores: semente, soja, melhoramento genético

\section{INTRODUCTION}

The federal plant breeding program for the majority of grain, oil and fiber crops was nomally designed to produce cultivars of high standards relating to yield, disease and insect resistance, environmental adaptability and some special parameters such as fiber and grain quality.

The majority of species we deal with to produce oil, fiber and grain rely on the seed as the major source of its reproduction and distribution. Therefore, seed technology plays an important role in the seed production system to ensure high seed quality with respect to its genetical, physiological and pathological standards.

In the case of soybean, one important contribution to the production system for the release of high quality seeds was DIACOM - Complete Diagnosis of Soybean Seed Quality (França Neto \& Henning, 1992), which is based on information provided by the tetrazolium test (vigor and viability) and the blotter test (pathology).

A significant approach to the production of soybean cultivars with high seed quality is based on 
the performance of the breeding seed lines following stress treatments during the vigor tests (Kueneman, 1981).

The contribution of seed scientist to the seed quality breeding program through the development of screening methods, can be of value in overcoming this problem, mainly for crops cultivated in tropical and subtropical environments.

\section{BREEDING FOR SEED QUALITY}

Successful cultivation of soybean in the tropics requires the availability of high-quality planting seed. Local production of such seed requires cultivars that are capable of enduring adverse climatic conditions usually present during the later stages of production and throughout most of the storage period. Good seed quality is also desirable in the subtropics because high soil temperature at planting and crusting of the soil surface may result in poor stands. The effects of pathogens can cause poor seed quality before physiological maturity, pre-harvest weathering, mechanical damage during and after harvest and deterioration during storage. Hot, dry weather during seed maturation can also result in poor quality seed (Toledo et al., 1994).

Genetic variability for soybean seed quality does exist. Several sources of high seed quality were identified, which confirmed the possibility of selecting for improving seed quality among soybean lines (Gilioli et al., 1981, 1982; Paludzyszyn et al.,1985, 1987; Kaster et al., 1988, 1989, 1993, 1996, 1997).

Several attributes of soybean that may contribute to improved seed quality are seed-coat properties, pod-wall permeability, resistance to fungi, seed size and cell wall permeability (FrançaNeto et al., 1994).

The mechanism of resistance to field weathering in soybean seed may be associated with pod-wall permeability (Tully, 1982; Pereira et al., 1985), seed-coat characteristics (Kueneman, 1981; Carbonell \& Krzyzanowski, 1995, Alvarez et al., 1997) and it has a relevant role in preventing the entry of pathogenic micro-organisms into the seeds (Miranda, 1977).

Soybean lines with small seeds seem to retain their quality better than those with larger seeds. Reduced susceptibility to mechanical damage during harvest and conditioning may be involved (Toledo et al., 1994).

Soybean seed quality is affected by shriveling due to heat and drought stresses during seed filling
(França-Neto et al., 1993). The screening of genotypes grown under such conditions based on field performance was carried out for four growing seasons (França Neto et al., 1996)

Evidence of genetic variability of seed cell wall permeability was observed in soybean cultivars (Krzyzanowski et al., 1997).

The breeding strategy used in tropical environments to screen soybean lines for seed quality relies basically on the accelerated aging test, with some modifications carried out by Wien \& Kueneman (1981), Dassou \& Kueneman (1984) and Kaster et al. (1989).

\section{THE ROLE OF SEED TECHNOLOGY RESEARCH IN THE BRAZILIAN SOYBEAN BREEDING PROGRAM}

A relationship between seed quality and pod characteristic was found by Pereira et al (1985) in their research program for evaluation of identification methods of genotypes with high seed quality, where the cultivar Sant'Ana had the best index for seed germination, vigor and health, which was due to its lower pod permeability among the 15 genotypes under evaluation.

Mottled seed, caused by the soybean mosaic virus (smv), is usually one of the parameters used to discard breeding lines. There was one assumption among breeders that this characteristic was associated with high physiological quality of the seeds. Krzyzanowski et al. (1989, 1993, 1996), evaluating 30 isolines for seed quality, were able to screen some genotypes produced under the same environmental conditions by using the tetrazolium test, with high seed quality among the resistant lines for smv.

Seed shriveling, due to heat and drought stresses during seed filling, affects seed quality, which is determined by germination, tetrazolium (vigor and viability), blotter and emergence in sand tests. Soybean seed quality was significantly reduced as the level of shriveling increased (França-Neto et al., 1993).

Mechanical damage is one of the causes of great loss of seed quality in tropical and subtropical environments. Developing cultivars that are less prone to mechanical damage are an important contribution from the breeders to the soybean growers for overcoming this limitation in addition to improving grain quality by reducing the amount of splits and cracks. Carbonell \& Krzyzanowski (1995) 
developed the pendulum test for identifying lines with seeds resistant to mechanical damage. Based on this test, 12 field grown soybean cultivars were classified as resistant, moderately resistant and susceptible categories. In the same line of research, Alvarez et al. (1997) were able to explain that the mechanical damage resistance of these cultivars were directly related to the amount of lignin content in the seed coat.

\section{REFERENCES}

ALVAREZ, P.J.C.; KRZYZANOWSKI, F.C.; MANDARINO, J.M.G.; FRANÇA-NETO, J.B. Relationship between soybean seed coat lignin content and resistance to mechanical damage. Seed Science and Technology, v.25, n.2, p.209-214, 1997.

CARBONELL, S.A.M; KRZYZANOWSKI, F.C. The pendulum test for screening soybean genotypes for seeds resistant to mechanical damage. Seed Science and Technology, v.23, n.2, p.331-339, 1995.

DASSOU, S.; KUENEMAN, E.A. Screening methodology for resistance to field weathering of soybean seed. Crop Science, v.24, n.4, p.774-779, 1984.

FRANÇA-NETO, J.B.; HENNING, A.A. DIACOM. Diagnóstico completo da qualidade da semente de soja. (Complete diagnosis of soybean seed quality). Londrina: EMBRAPA-CNPSo, 1992, $22 \mathrm{p}$.

FRANÇA-NETO, J.B.; HENNING, A.A.; KRZYZANOWSKI, F.C. Seed production and technology for the tropics. In: EMBRAPA-CNPSo. (Ed.) Tropical soybean: improvement and production. Rome: FAO, 1994. p.217-240.

FRANÇA-NETO, J.B.; KRZYZANOWSKI, F.C.; HENNING, A.A.; WEST, S.H.; MIRANDA, L.C. Soybean seed quality as affected by shriveling due to heat and drought stresses during seed filling. Seed Science and Technology, v.21, n.1, p.107-116, 1993.

FRANÇA-NETO, J.B.; KRZYZANOWSKI, F.C.; VAL, W.M.C.; COSTA. N.P.; YUYAMA, M.M.; ZORATO, M.F.; HENNING, A.A. Seleção de cultivares de soja quanto a tolerância ao enrugamento de sementes de soja decorrente da situação de estresse climático. (Screening soybeans cultivars for seed shriveling due stressful wheather conditions). In: SEMINARIOPANAMERICANO DE SEMILlAS, 15., Gramado, 1996. Anais. Gramado: CESM/RS, 1996. p.58.
GILIOLI, J.K.; KIIHL, R.A.S.; HENNING, A.A.; TOLEDO, J.F.F.; COSTA, N.P.; MAURO, A.O. Desenvolvimento de cultivares com alta qualidade de sementes. (Improvement of cultivars with high seed quality). In: EMPRESA BRASILEIRA DE PESQUISA AGROPECUÁRIA. Centro Nacional de Pesquisa da Soja. Resultados de Pesquisa de Soja: 1980/81. Londrina, EMBRAPA-CNPSo, 1981. p.28-30.

GILIOLI, J.L.; KIIHL, R.A.S.; BARRETO, J.N.; MAURO, A.O.; COSTA, N.P. Desenvolvimento de metodolgia e identificação de genótipos com alta qualidade fisiológica de sementes. (Methodology development and genotype identification of high physiological seed quality). In: EMPRESA BRASILEIRA DE PESQUISA AGROPECUÁRIA. Centro Nacional de Pesquisa da Soja. Resultados de Pesquisa de Soja: 1981/82. Londrina, EMBRAPA-CNPSo, 1982. p.137-146.

KASTER, M.; KIIHL, R.A.S.; KRZYZANOWSKI, F.C.; CARBONELL, S.A.M. Desenvolvimento de cultivares de soja com alta qualidade fisiológica da semente. (Improvement of soybean cultivars for high physiological seed quality). In: EMPRESA BRASILEIRA DE PESQUISA AGROPECUÁRIA. Centro Nacional de Pesquisa da Soja. Resultados de Pesquisa de Soja: 1987/88. Londrina, EMBRAPA- CNPSo, 1988. p.192-195. (Documento, 36)

KASTER, M.; KIIHL, R.A.S.; KRZYZANOWSKI, F.C.; CARBONELL, S.A.M. Desenvolvimento de cultivares de soja com alta qualidade fisiológica da semente. (Improvement of soybean cultivars for high physiological seed quality). In: EMPRESA BRASILEIRA DE PESQUISA AGROPECUÁRIA. Centro Nacional de Pesquisa da Soja. Resultados de Pesquisa de Soja:1988/89. Londrina: EMBRAPA-CNPSo, 1989. p.220-224. (Documento, 43)

KASTER, M.; KIIHL, R.A.S.; KRZYZANOWSKI, F.C. Desenvolvimento de cultivares de soja com alta qualidade fisiológica da semente. (Improvement of soybean cultivars for high physiological seed quality). In: EMPRESA BRASILEIRA DE PESQUISA AGROPECUÁRIA. Centro Nacional de Pesquisa da Soja Resultados de Pesquisa de Soja: 1989/90. Londrina, EMBRAPA-CNPSo, 1993. p.252-259. (Documento, 58) 
KASTER, M.; KIIHL, R.A.S.; KRZYZANOWSKI, F.C. Desenvolvimento de cultivares de soja com alta qualidade fisiológica da semente. (Improvement of soybean cultivars for high physiological seed quality). In: EMPRESA BRASILEIRA DE PESQUISA AGROPECUÁRIA. Centro Nacional de Pesquisa da Soja. Resultados de Pesquisa de Soja: 1990/91. Londrina, EMBRAPA-CNPSo, 1996. p.81-89. (Documento, 99)

KASTER, M.; KIIHL, R.A.S.; KRZYZANOWSKI, F.C. Desenvolvimento de cultivares de soja com alta qualidade fisiológica da semente. (Improvement of soybean cultivars for high physiological seed quality). In: EMPRESA BRASILEIRA DE PESQUISA AGROPECUÁRIA. Centro Nacional de Pesquisa da Soja. Resultados de Pesquisa da Embrapa Soja: 1996. Londrina: EMBRAPA-CNPSo, 1997. p.19-21. (Documento, 104)

KRZYZANOWSKI, F.C.; KIIHLS, R.A.S; MIRANDA, Z.F.S.; COSTA, N.P.; POLA, J.N.; OLIVEIRA, M.C.N. Relação entre resistência ao mosaico comum e qualidade fisiológica da semente de soja. (Relationship between soybean mosaic virus resistance and seed physiological quality ). In: EMPRESA BRASILEIRA DE PESQUISA AGROPECUÁRIA. Centro Nacional de Pesquisa da Soja. Resultados de Pesquisa de Soja: 1988/89. Londrina: EMBRAPA-CNPSo, 1989. p.315-318. (Documento, 43)

KRZYZANOWSKI, F.C.; KIIHLS, R.A.S; FRANÇANETO, J.B.; POLA, J.N., OLIVEIRA, M.C.N. Relação entre resistência ao mosaico comum e qualidade fisiológica da semente de soja. (Relationship between soybean mosaic virus resistance and seed physiological quality). In: EMPRESA BRASILEIRA DE PESQUISA AGROPECUÁRIA. Centro Nacional de Pesquisa da Soja. Resultados de Pesquisa de Soja: 1989/90. Londrina: EMBRAPA-CNPSo, 1993. p.397-398. (Documento, 58)

KRZYZANOWSKI, F.C.; KIIHLS, R.A.S; HENNING, A.A.; FRANÇA-NETO, J.B.; OLIVEIRA, M.C.N.; POLA, J.N. Relação entre resistência ao mosaico comum e qualidade fisiológica da semente de soja. (Relationship between soybean mosaic virus resistance and seed physiological quality). In: EMPRESA BRASILEIRA DE PESQUISA AGROPECUÁRIA. Centro Nacional de Pesquisa Agropecuária. Resultados de Pesquisa de Soja: 1990/91. Londrina: EMBRAPA-CNPSo, 1996. p.121-122. (Documento, 99)
KRZYZANOWSKI, F.C.; FRANÇA-NETO, J.B.; COSTA, N.P.; HENNING, A.A.; KASTER, M. Permeabilidade de membrana de célula de semente de soja. (Soybean seed cell membrane permeability) In: EMPRESA BRASILEIRA DE PESQUISA AGROPECUÁRIA. Centro Nacional de Pesquisa da Soja. Resultados de Pesquisa da Embrapa Soja: 1996. Londrina: EMBRAPA-CNPSo, 1997. p.146. (Documento, 104)

KUENEMAN, E.A. Genetic differences in soybean seed quality: Screening methods for cultivar improvement. In: SINCLAIR, J.B.; JACKOBS, J.A. (Ed.) Soybean seeds quality and stand establishment. Urbana: University of Illinois, 1981. p.31-41. (INTSOY Series, 22).

MIRANDA, F.M. Influence of some seed-borne pathogens and field weathering on soybean (Glycine $\max (L)$ Merril) seed quality. New Orleans, 1977. Thesis (M.S.) - Mississippi State University.

PALUDZYSZYN FILHO, E.; KIIHL, R.A.S.; SILVA, P.M.; ALMEIDA, L.A. Seleção de genótipos de alta qualidade fisiológica de sementes. (Genotype screening for high physiological seed quality). In: EMPRESA BRASILEIRA DE PESQUISA AGROPECUÁRIA. Centro Nacional de Pesquisa da Soja. Resultados de Pesquisa de Soja: 1984/85. Londrina: EMBRAPA-CNPSo, 1985. p. 274-280. (Documento, 15)

PALUDZYSZYN FILHO, E.; KIIHL, R.A.S.; SILVA, P.M.; ALMEIDA, L.A. Seleção de genótipos de alta qualidade fisiológica de sementes. (Genotype screening for high physiological seed quality). In: EMPRESA BRASILEIRA DE PESQUISA AGROPECUÁRIA. Centro Nacional de Pesquisa da Soja. Resultados de Pesquisa de Soja: 1985/86. Londrina: EMBRAPA-CNPSo, 1987. p.297-312. (Documento, 20)

PEREIRA, L.A.G.; HENNING, A.A.; FRANÇA-NETO; COSTA, N.P.; MAGALHÃES, C.V. Teste de metodologia para identificação de genótipos de alta qualidade fisiológica de sementes de soja. (Validation of methods for identifying soybean genotypes with high seed quality). In: EMPRESA BRASILEIRA DE PESQUISA AGROPECUÁRIA. Centro Nacional de Pesquisa da Soja. Resultados de Pesquisa de Soja: 1984/85. Londrina: EMBRAPA-CNPSo, 1985. p.407-420. (Documento, 15)

TOLEDO, J.F.F.; ALMEIDA, L.A.; KIIHL, R.A.S.; PANIZZI, M.C.; KASTER, M.; MIRANDA, L.C.; MENOSSO, O.G. Genetics and breeding. In: EMBRAPA-CNPSo. (Ed.). Tropical soybean: improvement and production. Rome: FAO, 1994. p.19-36. 
TULLY, R.E. A new technique for measuring permeability of dry soybean pods to water. Crop Science, v.22, n.2, p.437-440, 1982.

WIEN, H.C.; KUENEMAN, E.A. Soybean seed deterioration in the tropics: II. Variety differences and techniques for screening. Field Crops Research, v.4, p.123-132, 1981.
Recebido para publicação em 10/07/98 Aceito para publicação em 03/08/98 